https://doi.org/10.4314/jpb.v17i1.7

Vol. 17 no. 1, pp. 34-43 (March 2020)

http://ajol.info/index.php/jpb

\section{Journal of \\ PHARMACY AND \\ BIORESOURCES}

\title{
Formulation and evaluation of sustained release diclofenac sodium matrix tablets produced using Brachystegia eurycoma gum
}

\author{
Sinodukoo E. OKAFO*, John A. AVBUNUDIOGBA and Ejiro EJOMAFUVWE \\ Department of Pharmaceutics and Industrial Pharmacy, Faculty of Pharmacy, Delta State University, Abraka.
} Nigeria.

Received $24^{\text {th }}$ November 2019; Accepted $31^{\text {st }}$ January 2020

\begin{abstract}
This study was carried out to evaluate sustained release diclofenac sodium matrix tablets formulated using Brachystegia eurycoma gum (BEG) as matrix polymer. BEG was isolated by acetone -precipitation of the filtrate obtained from the maceration of powdered dried seeds of Brachystegia eurycoma in distilled water. Diclofenac sodium matrix tablets were produced by non-aqueous wet granulation method using BEG as the hydrophilic matrix former. The tablets were evaluated using official and unofficial tests such as; uniformity of weight, content uniformity, dissolution test, tablets diameter, thickness, hardness and friability tests. The drug release profile of the matrix tablets were compared to that formulated using a standard matrix former, hydroxypropylmethylcellulose (HPMC). Hardness values ranged from $6.12 \pm 1.80$ to $9.73 \pm 1.39 \mathrm{kgf}$, friability from $0.31 \pm 0.00$ to $1.00 \pm 0.00 \%$. The drug content ranged from 98 to $101 \%$. The percentage drug released from the matrix tablets after $10 \mathrm{~h}$ was between 71.27 and $98.73 \%$ except for formulation BF3 that released $32.56 \%$. This study showed that sustained release diclofenac sodium matrix tablets were successfully formulated using Brachystegia eurycoma gum as the matrix former and the tablets were comparable to that formulated with HPMC.
\end{abstract}

Keywords: Brachystegia eurycoma gum; Diclofenac sodium; Matrix tablets; Sustained release

\section{INTRODUCTION}

Arthritis and many other rheumatic diseases are mainly disorders of the supportive or connective tissues of the bones, tendons, heart valves and joints ranging from minor stiffness to serious disability and deformity [1]. Pain is the major complaint by patients who have arthritis. The pain from arthritis is due to inflammation that occurs around the joint, damage to the joint from disease, daily wear and tear of joints, muscle strains caused by forceful movements against stiff, painful joints and fatigue. There is no cure for either rheumatoid or osteoarthritis but the disease can be managed through amelioration of symptoms. Non-steroidal antiinflammatory drugs (NSAIDs) block Cox enzymes and reduce production of prostaglandins thereby producing relief from inflammation, pain and fever [2].

The phenylacetic acid derivatives such as diclofenac are one of the many classes of drugs that are known as NSAIDs. Diclofenac contains not less than 99.0 per cent and not

*Correspondence. E-mail: sinokaf@yahoo.com Tel: +234-8063386118.

ISSN 0189-8442

(cc) BY-Nc 2020 Published by Faculty of Pharmaceutical Sciences, University of Jos, Nigeria. Under Creative Commons Attribution-NonCommercial 4.0 International License. https://creativecommons.org/licenses/by-nc/4.0/ 
more than the equivalent of 101.0 per cent of Sodium 2-[(2,6-dichlorophenyl) amino] phenyl acetate, calculated with reference to the dried substance [3]. Diclofenac is commonly used as two of its salt form namely potassium and sodium. Diclofenac potassium has faster onset of action. It is mainly used in acute cases while diclofenac sodium has slower onset of action and is used mainly in chronic cases such as rheumatoid arthritis. Diclofenac is used for long-term symptomatic treatment of rheumatoid arthritis, osteoarthritis and ankylosing spondylitis [4]. Rheumatoid arthritis and osteoarthritis are chronic diseases and their management requires use of drug for a long period. The usual dose of diclofenac sodium in osteoarthritis is $50 \mathrm{mg}$ two to three times daily or $75 \mathrm{mg}$ twice daily. In rheumatoid arthritis, the dose is $50 \mathrm{mg}$ three to four times daily or $75 \mathrm{mg}$ twice daily [2,5]. Compliance is usually a problem. Sustained-release diclofenac sodium $100 \mathrm{mg}$ tablet is given once daily. This improves compliance and ultimately therapeutic success.

A sustained-release tablet is a drug product formulation that provides the required dosage initially and then maintains or repeats it at desired intervals. Sustained-release tablets are designed to release the drug slowly after ingestion [6,7]. The main factor in the more widespread use of these types of dosage forms is that patient compliance is improved, since only one or two tablets need to be taken daily [8].

The matrix system is commonly used for manufacturing sustained-release dosage forms because it makes such manufacturing easy. A wide array of polymers has been employed as drug retarding agents each of which presents a different approach to the matrix concept [9]. Uncoated sustainedrelease tablets are prepared by embedding the drug in the tablet matrix [10]. The hydrophilic matrix system, when exposed to an aqueous medium does not disintegrate but immediately after hydration develops a highly viscous gelatinous surface barrier, which controls the drug release from, and liquid penetration into the centre of the matrix system [11-13]. The primary rate limiting ingredients of hydrophilic matrix are polymers that would swell when in contact with aqueous solution and form a gel layer on the surface of the system. When the release medium is thermodynamically compatible with a polymer, the solvent penetrates into the free spaces between macromolecular chains. The polymer may undergo a relaxation process due to the stress of the penetrated solvent, so that the polymer chains become more flexible and the matrix swells. This allows the embedded drug to diffuse quicker out of the matrix [14]. On the other hand, it would take longer time for drug to diffuse out of the matrix since matrix swelling lengthens the diffusion path. It has been widely known that swelling and diffusion are not the only factors that determine the rate of drug release. Polymer dissolution is another important mechanism that can modulate the drug delivery rate for dissolvable polymer matrix. While either swelling or dissolution can be the major factor for a specific type of polymers, in most cases drug release kinetics is a result of a combination of these two mechanisms $[7,14]$. The main polymers used in hydrophilic matrices are hydroxypropyl methyl cellulose (HPMC) and hydroxypropyl cellulose (HPC), xanthan gum, carbopol and alginates $[15,16]$. Other natural gums have been used in the formulation of hydrophilic matrix tablets. They include Araucaria bidwilli gum [17], Tamarind seed polysaccharide [18].

Brachystegia eurycoma belongs to the family Caesalpiniaceae; phylum spermatophyte and order Fabaceae [19]. It is a woody plant mostly found in the forest zone. The seed contains $10.47 \%$ protein and total carbohydrate content of $71.94 \%$. It is usually called Achi by the Igbos, Akalado or Eku by 
Yorubas, Akpakpa or Apaupan by the Ijaw and Okwen by the Edos [20]. Brachystegia eurycoma (Achi) seed flour has good gelation properties [19]. Brachystegia eurycoma gum was investigated in ameliorating brittle fracture during tableting when used as binders in tableting [21]. BEG was successfully evaluated as suspending agent in metronidazole suspensions [22].

Sustained release diclofenac sodium matrix tablets have been formulated using different polymers $[17,18,23,24]$ but literature search showed no evidence of use of Brachystegia eurycoma gum. Brachystegia eurycoma tree is found in abundance in southern Nigeria and gum can easily be obtained from its seeds.

The aim of this study was to evaluate sustained release diclofenac sodium matrix tablets formulated using Brachystegia eurycoma gum.

\section{EXPERIMENTAL}

Materials. Isopropyl alcohol, acetone, (Guangxing Guanghua Chemical, China), potassium dihydrogen orthophosphate, dipotassium hydrogen phosphate (BDH Chemicals Ltd Poole England), diclofenac, (Alpha Lab, Germany), hydroxylpropyl methylcellulose, lactose, polyvinyl pyrrolidone, magnesium stearate (Mira Organics and Chemical Co. Ltd. Chennai, India), sodium hydroxide (Loba Chemie, Mumbia, India), were of analytical grade. Brachystegia eurycoma gum was isolated from Brachystegia eurycoma seeds obtained from a local market in Abraka, Delta state, Nigeria.

\section{Extraction of Brachystegia eurycoma Gum}

Brachystegia eurycoma gum was isolated using the method of Uzondu et al. [25] with modification. Two litres of water was added to Brachystegia eurycoma seeds in a container and kept for $5 \mathrm{~h}$. This helped to ease hull removal. The seeds were de-hulled manually, dried for $6 \mathrm{~h}$ and pulverized with a blender (Qlink Model no.QBL-20L330). One hundred and fifty gram of the powdered Brachystegia eurycoma seeds was weighed, boiled with $1.5 \mathrm{~L}$ of distilled water for an hour and then soaked in $2.5 \mathrm{~L}$ of distilled water for 24 hours. It was filtered with a muslin cloth. Acetone was added to the filtrate in a ratio of $1: 2$ to precipitate the gum. The gum was further washed with $500 \mathrm{ml}$ of acetone and then dried in an oven (Leader engineering St Helen, Model: GP/50/CLAD/100/HVD) at $50^{\circ} \mathrm{C}$ for $6 \mathrm{~h}$. The dry flakes were pulverized using a blender and stored in an airtight container.

Formulation of the matrix tablets. Diclofenac sodium matrix tablets were formulated using the formula in Table 1. Granules were prepared using the nonaqueous wet granulation technique. Diclofenac sodium (100 mg) was weighed and transferred into a mortar. This was mixed uniformly with $50 \mathrm{mg}$ of Brachystegia eurycoma gum and $310 \mathrm{mg}$ of lactose using a pestle. Polyvinyl pyrollidone $(25 \mathrm{mg})$ was dissolved with sufficient quantity of isopropyl alcohol, added to the powder, mixed and blended uniformly to form a damp mass. The wet mass was passed through a $1.18 \mathrm{~mm}$ sieve (Sethi standard test sieve) to form granules. The wet granules were dried in an oven (Leader engineering St Helen, Model: GP/50/CLAD/100/HVD) at $40^{\circ} \mathrm{C}$ for $1 \mathrm{~h}$., after which the dried granules were sieved with a $710 \mu \mathrm{m}$ sieve (Sethi standard test sieve). Magnesium stearate and talc were added to the granules and then compressed into tablets with a predetermined force using a CJD 316 sixteen-station rotary tablet press with $13 \mathrm{~mm}$ punch (Clit Jemkay Engs. Pvt, Ltd. Ahmedabad, India). This procedure was repeated following the formula on Table 1 to prepare formulations BF2 to BF6 tablets.

\section{Characterisation of granules}

Flow rate. From formulation $\mathrm{BF} 1,10 \mathrm{~g}$ of granules was weighed and transferred into a funnel in which the orifice was closed with a 
shutter. The shutter was removed from the orifice to allow the granules flow out. The time taken for the granules to discharge completely from the orifice was recorded. The procedure was repeated two more times and the mean flow time was calculated. The procedure was repeated for formulations $\mathrm{BF} 2$ to BF6. The flow rate was calculated using equation 1.

Flow rate $=\frac{\text { mass of granules }(g)}{\operatorname{time}(s)} \ldots \ldots .1$

Bulk density. Ten grams of granules was weighed from formulation BF1 and transferred into a $100 \mathrm{ml}$ measuring cylinder. The volume occupied by the granules was recorded as the bulk volume. The procedure was repeated two more times and the mean bulk volume was determined. The procedure was repeated for $\mathrm{BF} 2$ to $\mathrm{BF} 6$. The bulk density was calculated using equation 2 .

Bulk density $=\frac{\text { mass of granules }(g)}{\text { bulk volume }(m l)} \ldots \ldots 2$

Tapped density. A 10 g quantity of granules was weighed from formulation BF1 and was transferred into a $100 \mathrm{ml}$ measuring cylinder. The measuring cylinder was tapped 100 times and the new volume occupied by the granules was recorded as the tapped volume. The procedure was repeated two more times and the mean tapped density calculated. This was repeated for formulation BF2 to BF6. Tapped density was calculated using equation 3 .

Tapped density $=\frac{\text { mass of grawules }(\mathrm{g})}{\text { tapped volume }(\mathrm{ml})}$. . 3

Angle of repose: A $10 \mathrm{~g}$ quantity of granules from formulation BF1 was weighed and allowed to flow from a funnel onto a flat horizontal surface so that it formed a cone. The height and the base of the cone formed were measured and recorded. This was repeated two more times and the mean value calculated. The same procedure was repeated for formulations $\mathrm{BF} 2$ to $\mathrm{BF} 6$. The angle of repose was calculated using equation 4 .

$$
\text { Tane }=\frac{2 h}{d} \ldots \ldots \ldots \ldots 4
$$

Where $\mathrm{h}=$ height of cone, $\mathrm{d}=$ diameter of the base of cone
Compressibility index. This was calculated from the bulk and tapped densities using equation 5

Carr's index

$$
=\frac{\text { tapped density-bulk density }}{\text { tapped density }} \times 100 \ldots \ldots 5
$$

Hausner's ratio. This was calculated using equation 6.

$$
\text { Hausner's ratio }=\frac{\text { tapped density }}{\text { bulk density }} \ldots \ldots .6
$$

Evaluation of diclofenac sodium tablets.

The formulated diclofenac matrix tablets were evaluated based on official and unofficial tests.

Hardness test. Ten tablets from formulation BF1 were selected at random and hardness of each tablet was determined using a digital hardness tester (Veego digital hardness test apparatus, Veego Instruments, India). The machine was also used to determine the diameter and thickness of the tablets. This procedure was repeated for formulations BF2 to BF6.

Friability test. Ten tablets were randomly selected from formulation BF1. The tablets were weighed together and the total weight was recorded as initial weight. The tablets were placed in a friabilator (Veego friability tester) and rotated 100 times. The tablets were dusted and reweighed. The new weight was recorded as the final weight. The same procedure was repeated for tablets from formulations $\mathrm{BF} 2$ to BF6. Friability was determined using equation 7.

$\%$ friability

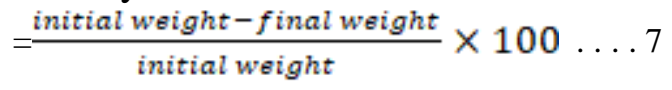

Weight uniformity test. Twenty (20) tablets from each formulation were randomly selected and weighed individually. The mean weight was calculated and the percentage deviation from the mean was determined.

Content uniformity test. Uniformity test for drug content was carried out by selecting at random 10 tablets from each formulation. The tablets were crushed in a mortar and quantity 
of the powder that contained the claimed weight of the active pharmaceutical ingredients was dissolved in $100 \mathrm{ml}$ phosphate buffer $\mathrm{pH}$ 6.8. From the solution, $10 \mathrm{ml}$ was taken and diluted to $100 \mathrm{ml}$. The absorbance was read using Carry 60 model UV - VIS spectrophotometer (Agilent Technologies, Malaysia) at a wavelength of $276 \mathrm{~nm}$.

In vitro dissolution test: This test was carried out using the rotating basket method. A 900 $\mathrm{ml}$ quantity of phosphate buffer of $\mathrm{pH} 6.8$ was used as the dissolution medium. One tablet of diclofenac sodium was weighed and placed in the basket of a single unit Copley dissolution test apparatus (Erweka Apparatebau GMBH, Heusengtamm, Germany). The basket was inserted into the dissolution chamber that was maintained at $37 \pm 1^{\circ} \mathrm{C}$ and rotated at a speed of $100 \mathrm{rpm}$. At predetermined time intervals of $0.5,1,2$ to $10 \mathrm{~h}, 5 \mathrm{ml}$ of the medium was withdrawn with a syringe and replaced with equal volume of preheated fresh medium. The samples withdrawn were filtered and analyzed using the Carry 60 model UV - VIS spectrophotometer (Agilent Technologies, Malaysia) at a wavelength of $276 \mathrm{~nm}$.

Kinetics and mechanism of drug release. The kinetics of drug release was determined by applying various kinetic models (equation 8 to 13 ) to the in vitro drug release from the matrix tablets [23,26-28]. The mechanism of drug release was determined by fitting the first $60 \%$ drug release data into the Korsmeyer-Peppas model using equation 12 and 13 [23,29,30]

Zero Order Model: $\mathrm{C}=\mathrm{K}_{0} \mathrm{t} \ldots \ldots \ldots$ (8)

$\mathrm{C}=\%$ release, $\mathrm{K}_{0}=$ zero order rate constant expressed in units of concentration/time $(\mathrm{t})$.

First Order Model:

$\log C_{r}=\log C_{0}-K_{1} t / 2.303 \ldots \ldots$. . . (9)

$\mathrm{C}_{\mathrm{r}}=\%$ Remaining, $\mathrm{C}_{0}=$ Initial concentration of drug,

$\mathrm{K}_{1}=$ first order constant, $\mathrm{t}=$ time

Higuchi's Square root Law Model:

$\mathrm{Q}=\mathrm{K}_{\mathrm{H}} \mathrm{t}_{1 / 2} \ldots \ldots \ldots \ldots \ldots$ (10)

$\mathrm{Q}=\%$ Released, $\mathrm{K}_{\mathrm{H}}=$ Constant reflecting design variables of the system, $\mathrm{t}=$ time
Hixson - Crowell's Cuberoot Law Model: [(100 f) $/ 100]^{1 / 3}=1-\mathrm{K}_{\mathrm{HCt}} \ldots \ldots$ (11)

$\mathrm{f}=\%$ Released, $\mathrm{K}_{\mathrm{HC}}=$ rate constant, $\mathrm{t}=$ time

Korsmeyer - Peppas Model: $\mathrm{M}_{\mathrm{t}} / \mathrm{M}_{\infty}=\mathrm{Kt}^{\mathrm{n}} \ldots$. (12)

$\log \mathbf{M}_{t} / \mathbf{M}=\log \mathrm{K}+\mathrm{n} \log \mathrm{t} \ldots \ldots \ldots \ldots$ (13)

Where, $M_{t} / M_{\infty}$ is the fraction of drug released at time $t, k$ is the rate constant and $n$ is the release exponent.

Drug-excipients compatibility studies. This was determined by the use of Fourier transformed infrared spectroscopy (FTIR). FTIR studies were performed on drug and drug-excipients mix respectively using Shimadzu FTIR (Shimadzu Corp., Japan). About 2-3 mg of samples were mixed with the dried IR grade potassium bromide powder and analyzed between wave numbers 4000 and $400 \mathrm{~cm}^{-1}$.

Data analysis. Statistical analysis was done using Microsoft Excel. Data were analyzed by one-way ANOVA. Differences between means were assessed by a two - tailed student's t-test. $\mathrm{P}<0.05$ was considered statistically significant.

\section{RESULTS AND DISCUSSION}

Characterisation of diclofenac sodium granules. Flow rate is a direct measure of powder flow. From Table 2, the flow rate of the granules decreased from BF1 to BF6. Granules from formulations BF1 to BF3 have better flow property when compared to those from BF4 to BF6. This may be due to the size and shape of the granules formed which will ultimately affect the packing geometry of the granules, the porosity and flow property. Hausner's ratio, Carr's index and angle of repose are indirect measures of powder flow. As shown on Table 2, with the angles of repose values ranging from $24.48 \pm 0.31$ to $33.31 \pm 1.34$, Carr's index of $6.25 \pm 0.00$ to $20.23 \pm 0.00$, and Hausner's ratio of $1.07 \pm$ 0.00 to $1.25 \pm 0.00$, it could be inferred that granules from all the formulations exhibited good flow property. Good powder flow is essential as it ensures tablet weight uniformity 
and reduces the risk of weight variation within a batch. Tablet capping and lamination can be reduced when granules have good flowing property.

Evaluation of diclofenac matrix tablets. The BP specification for tablets weighing more than $250 \mathrm{mg}$ states that, no two tablets from a batch should vary by more or less than $5 \%$ of the mean weight [3]. The weights of the tablets from the different formulations ranged from $490.2 \mathrm{~g}$ to $507.0 \mathrm{mg}$. The mean tablet weight as shown on Table 3 ranged from $497.56 \pm 3.46$ to $499.14 \pm 2.08 \mathrm{mg}$ for the different formulations. They all conformed to the BP specification for weight uniformity. The implication of uniformity of weight of tablets is that each tablet would contain the stated amount of the active drug in the dosage form and therefore give therapeutic result when used. Tablet strength is usually determined by its level of hardness as well as its level of friability. A tablet should be able to withstand certain degree of mechanical shock during handling, transportation and abuse in the hands of the patient. From Table 3, it can be seen that the hardness of the tablets from the different formulations was between $6.12 \pm 1.80$ to 9.73 $\pm 1.39 \mathrm{kgf}$. In addition, the friability of the tablets from the different formulations was between 0.3 and $1.0 \%$. Friability is an index of tablet strength. It is a disruptive force used to evaluate tablets ability to withstand mechanical shock. A maximum friability value of $1 \%$ is usually acceptable [31]. Diclofenac sodium extended-release tablets contain not less than 90.0 percent and not more than 110.0 per cent of the labeled amount of diclofenac sodium [32]. From the result obtained (98-101\%) as shown on Table 3 , the matrix tablets from all the formulations passed the drug content test. It is important for the matrix tablets to have uniform content of the active ingredients, as this would guarantee the therapeutic effectiveness of all the tablets produced.

In vitro drug release profile. From Figure 1, BF1 which contained $10 \%$ of BEG released $100 \%$ of its drug content within $4 \mathrm{~h}$ while BF2 which contained $20 \%$ of the gum released $72 \%$ of the drug after $10 \mathrm{~h}, \mathrm{BF} 3$ with $30 \%$ of the gum released only $32 \%$ of the drug after $10 \mathrm{~h}$. It showed that the higher the concentration of the gum, the higher the retardation of drug release. Hydrophilic polymers swell and form gel upon contact with water. The drug embedded in the polymer matrix is released mainly by diffusion through the gel layer and also by erosion. The higher the concentration of the polymer, the thicker the gel formed and the higher the drug release retarding effect. The formulation that contained $20 \%$ of $\mathrm{BEG}$ (BF2) seems to be the optimum as it achieved $72 \%$ drug release after $10 \mathrm{~h}$, which will make it useful as a once daily dosage drug. BEG has higher drug retarding effect than HPMC. At $30 \%$ polymer concentration, BF3 (BEG) released $32 \%$ of diclofenac sodium while BF6 (HPMC) released $72 \%$ after $10 \mathrm{~h}$.

Table 1: Composition of diclofenac sodium matrix tablets from formulations BF1 to BF6

\begin{tabular}{lllllll}
\hline Ingredients & BF1 & BF2 & BF3 & BF4 & BF5 & BF6 \\
\hline Diclofenac sodium (mg) & 100 & 100 & 100 & 100 & 100 & 100 \\
BEG (mg) & 50 & 100 & 150 & - & - & - \\
HPMC (mg) & - & - & - & 50 & 100 & 150 \\
Lactose (mg) & 310 & 260 & 210 & 310 & 260 & 210 \\
Polyvinyl pyrollidone (mg) & 25 & 25 & 25 & 25 & 25 & 25 \\
Isopropyl alcohol (mg) & Qs & Qs & Qs & Qs & Qs & qs \\
Talc (mg) & 10 & 10 & 10 & 10 & 10 & 10 \\
Mg stearate (mg) & 5 & 5 & 5 & 5 & 5 & 5 \\
Total (mg) & 500 & 500 & 500 & 500 & 500 & 500 \\
\hline EG = Brachystegia eurycoma gum, HPMC $=$ hydroxypropyl methylcellulose
\end{tabular}


Table 2: Characterization of granules

\begin{tabular}{lllllll}
\hline F & $\begin{array}{l}\text { Flow rate }(\mathrm{g} / \mathrm{s}) \\
\pm \mathrm{SD}\end{array}$ & $\begin{array}{l}\text { Angle of repose } \\
\left({ }^{\circ}\right) \pm \mathrm{SD}\end{array}$ & $\begin{array}{l}\text { Carr's index }(\%) \\
\pm \mathrm{SD}\end{array}$ & $\begin{array}{l}\text { Hausner's ratio } \\
\pm \mathrm{SD}\end{array}$ & $\begin{array}{l}\text { Bulk density } \\
\left(\mathrm{g} / \mathrm{cm}^{3}\right) \pm \mathrm{SD}\end{array}$ & $\begin{array}{l}\text { Tapped density } \\
\pm \mathrm{SD}\end{array}$ \\
\hline $\mathrm{BF} 1$ & $2.58 \pm 0.11$ & $24.48 \pm 0.31$ & $10.61 \pm 0.00$ & $1.12 \pm 0.00$ & $0.60 \pm 0.00$ & $0.65 \pm 0.00$ \\
$\mathrm{BF} 2$ & $2.56 \pm 0.02$ & $26.45 \pm 0.65$ & $6.25 \pm 0.00$ & $1.07 \pm 0.00$ & $0.62 \pm 0.00$ & $0.66 \pm 0.00$ \\
$\mathrm{BF} 3$ & $2.72 \pm 0.08$ & $27.01 \pm 1.90$ & $7.69 \pm 0.00$ & $1.08 \pm 0.00$ & $0.63 \pm 0.00$ & $0.69 \pm 0.00$ \\
$\mathrm{BF} 4$ & $1.57 \pm 0.02$ & $29.84 \pm 0.3$ & $14.29 \pm 0.00$ & $1.17 \pm 0.00$ & $0.42 \pm 0.00$ & $0.49 \pm 0.00$ \\
$\mathrm{BF5}$ & $1.49 \pm 0.02$ & $30.84 \pm 0.91$ & $12.31 \pm 0.00$ & $1.14 \pm 0.00$ & $0.39 \pm 0.00$ & $0.45 \pm 0.00$ \\
$\mathrm{BF} 6$ & $1.23 \pm 0.01$ & $33.31 \pm 1.34$ & $20.23 \pm 0.00$ & $1.25 \pm 0.00$ & $0.32 \pm 0.00$ & $0.41 \pm 0.00$ \\
\hline \multicolumn{7}{c}{$\mathrm{F}=$ formulation code }
\end{tabular}

Table 3: Evaluation of the Matrix Tablets

\begin{tabular}{cclllll}
\hline F & $\begin{array}{l}\text { Hardness } \pm \\
\text { SD }(\text { Kgf })\end{array}$ & $\begin{array}{l}\text { Friability } \pm \\
\text { SD }(\%)\end{array}$ & $\begin{array}{l}\text { Diameter } \pm \\
\text { SD }(\mathrm{mm})\end{array}$ & $\begin{array}{l}\text { Thickness } \pm \\
\text { SD }(\mathrm{mm})\end{array}$ & $\begin{array}{l}\text { Drug } \\
\text { content }(\%)\end{array}$ & $\begin{array}{c}\text { Uniformity of } \\
\text { weight }(\mathrm{mg})\end{array}$ \\
\hline BF1 & $9.73 \pm 1.39$ & $0.49 \pm 0.00$ & $13.04 \pm 0.04$ & $3.06 \pm 0.06$ & 98.0 & $498.95 \pm 5.00$ \\
BF2 & $7.57 \pm 0.59$ & $0.72 \pm 0.00$ & $12.88 \pm 0.02$ & $3.00 \pm 0.09$ & 99.9 & $497.56 \pm 3.46$ \\
BF3 & $7.70 \pm 1.50$ & $1.00 \pm 0.00$ & $12.93 \pm 0.04$ & $3.20 \pm 0.17$ & 98.0 & $497.99 \pm 2.72$ \\
BF4 & $8.15 \pm 0.79$ & $0.31 \pm 0.00$ & $12.89 \pm 0.04$ & $3.13 \pm 0.13$ & 99.9 & $498.92 \pm 2.17$ \\
BF5 & $6.12 \pm 1.80$ & $0.9 \pm 0.00$ & $12.99 \pm 0.04$ & $3.35 \pm 0.19$ & 101.0 & $498.50 \pm 2.53$ \\
BF6 & $6.47 \pm 2.25$ & $0.9 \pm 0.00$ & $12.95 \pm 0.00$ & $3.47 \pm 0.04$ & 98.0 & $499.14 \pm 2.08$ \\
\hline
\end{tabular}

$\mathrm{SD}=$ Standard deviation; $\mathrm{F}=$ Formulation codes

Table 4: Kinetics of drug release

\begin{tabular}{llrrrrrr}
\hline KINETIC MODEL & & BF1 & BF2 & BF3 & BF4 & BF5 & \multicolumn{1}{l}{ BF6 } \\
\hline \multirow{3}{*}{ Zero Order } & $\mathrm{K}$ & 13.52 & 7.48 & 3.507 & 7.632 & 11.64 & 9.325 \\
& $\mathrm{R}^{2}$ & 0.043 & $\mathbf{0 . 9 8 5}$ & 0.912 & 0.973 & 0.315 & 0.563 \\
First Order & $\mathrm{K}_{1}$ & 1.009 & 0.131 & 0.035 & 0.122 & 0.228 & 0.129 \\
& $\mathrm{R}^{2}$ & $\mathbf{0 . 9 6 5}$ & 0.957 & $\mathbf{0 . 9 6 8}$ & 0.981 & 0.971 & 0.969 \\
Higuchi Square Root Law & $\mathrm{K}_{\mathrm{H}}$ & 37.36 & 19.29 & 9.215 & 19.92 & 31.73 & 25.21 \\
& $\mathrm{R}^{2}$ & 0.697 & 0.827 & 0.885 & 0.893 & 0.946 & 0.973 \\
Hixon Crowell Cuberoot & $\mathrm{K}_{\mathrm{HC}}$ & 0.214 & 0.033 & 0.013 & 0.033 & 0.064 & 0.043 \\
& $\mathrm{R}^{2}$ & 0.909 & 0.959 & 0.935 & 0.988 & 0.834 & 0.837 \\
& $\mathrm{~K}$ & 0.25 & 0.152 & 0.246 & 0.148 & 0.369 & 0.319 \\
Korsmeyer Peppas & $\mathrm{R}^{2}$ & 0.807 & 0.946 & 0.897 & $\mathbf{0 . 9 9 3}$ & $\mathbf{0 . 9 7 9}$ & $\mathbf{0 . 9 7 6}$ \\
& $\mathrm{N}$ & 0.747 & 0.775 & 0.552 & 0.84 & 0.481 & 0.533 \\
\hline
\end{tabular}

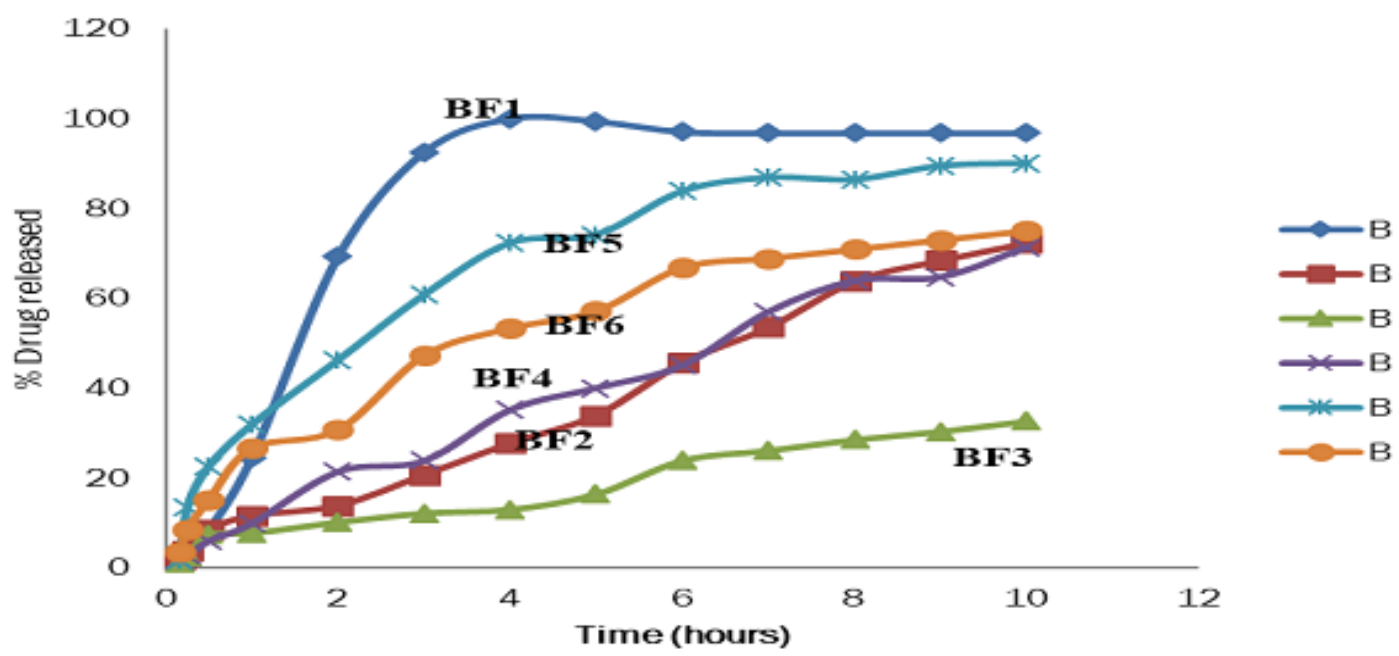

Fig 1: In vitro drug release profile for formulations BF1 to BF6

BF1 (10\% BEG); BF2 (20\% BEG); BF3 (30\% BEG); BF4 (10\% HPMC); BF5 (20\% HPMC), BF6 (30\% HPMC) 

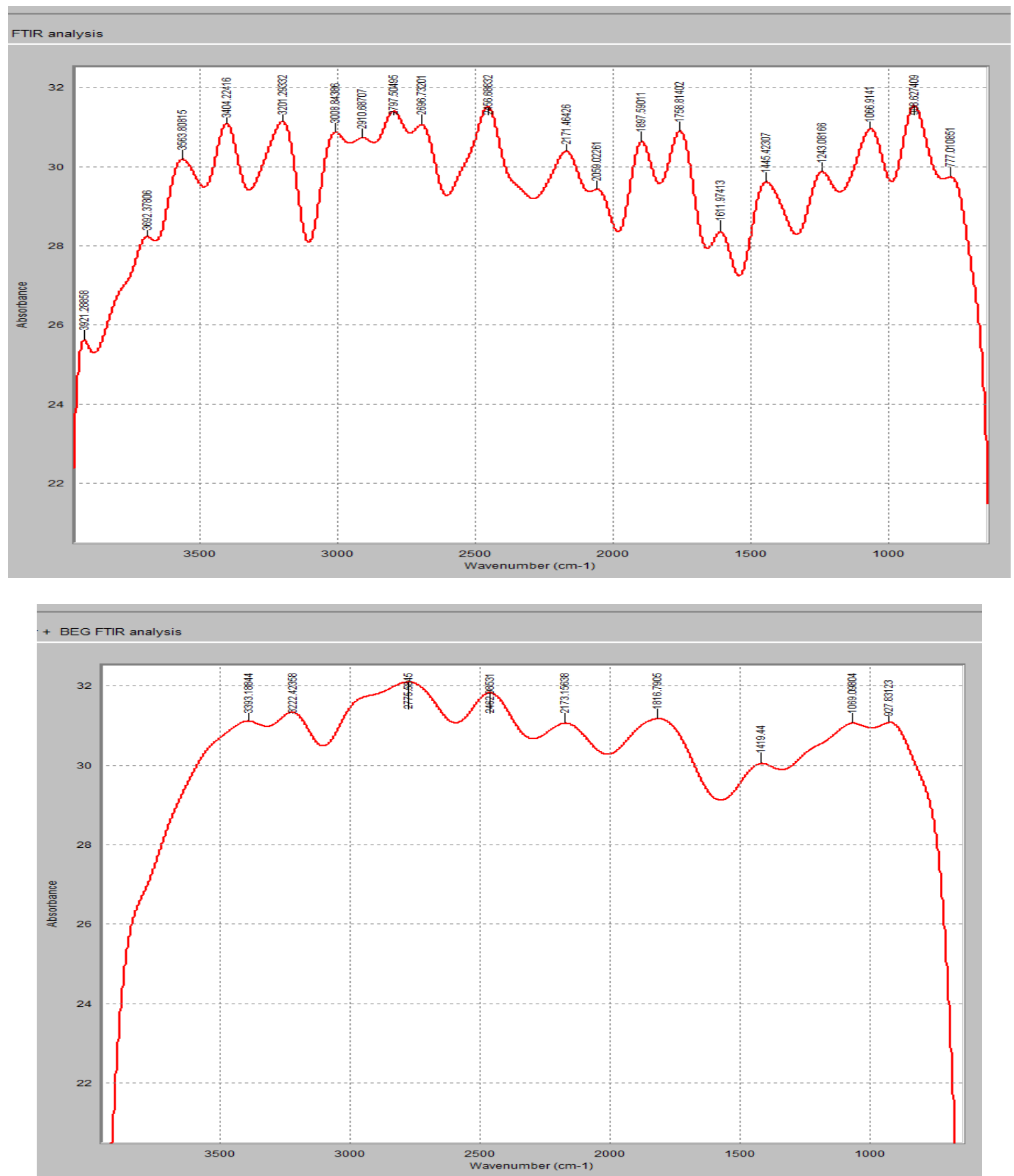

Figure 2: (a) FTIR spectrum of diclofenac (b) FTIR spectra of diclofenac plus Brachystegia eurycoma gum

Kinetics and mechanism of release. The kinetics of release was dominated by first order except in formulation BF2 where zero order was the dominant model, however, in all the formulations other models still contributed to the release kinetics beside the dominant model. The mechanism of release of diclofenac from the various matrix tablet formulations as shown by the $\mathrm{n}$ value was by non-Fickian or anomalous mechanism, since the various $\mathrm{n}$ - values were greater than 0.45 but less than 0.89. This shows that the drug release mechanism may be through a combination of diffusion and erosion. This 
was in agreement with the report of [24] in which they formulated diclofenac sodium sustained release matrix tablets using coprocessed excipients of cross-linked amylose-xanthan gum as matrix.

The study showed that Brachystegia eurycoma gum at appropriate concentration could be used as a matrix former in the formulation of sustained-release diclofenac sodium matrix tablets. The tablets formulated were comparable to those obtained using a standard polymer, HPMC.

\section{Drug-excipients compatibility studies}

FTIR spectra of diclofenac sodium and mixture of diclofenac sodium and BEG are shown in Figure 2. The spectrum of diclofenac sodium showed infrared band peaks, at around $1611.974 \mathrm{~cm}^{-1} \quad(\mathrm{C}=\mathrm{C})$, $3201.293 \mathrm{~cm}^{-1}$ (COOH carboxylic acid) and $3404.224 \mathrm{~cm}^{-1}$ (NH amine). FTIR spectrum of diclofenac - BEG mixture showed the characteristic peaks of the pure drug diclofenac sodium. This shows that there was no shifting in the frequencies of above said functional groups, therefore it can be inferred that there was no drug and excipients incompatibility.

Acknowledgement. The authors wish to express their gratitude to the Department of Pharmaceutics and Industrial Pharmacy, Faculty of Pharmacy, Delta State University, Abraka, Nigeria, for allowing the use of her laboratory for the research.

\section{REFERENCES}

1. Mradul, R. G.; Rahul, K.; Sudheesh, M. S. and Umesh, K. P. (2010); An applauded novel drug delivery system for arthritis using NSAIDS by microencapsulation technique -A review; Der Pharmacia Lettre. 2(4), 335-354.

2. Grosser, T; Smyth, E and FitzGerald, G. A. (2011); Anti-inflammatory, antipyretic, and Analgesic agents, pharmacotherapy of Gout; In: Brunton, L. L (Ed.) Goodman and Gilman's The Pharmacological Basis of Therapeutics; $12^{\text {th }}$ Ed., McGraw-Hill, New York pp 959-1004.

3. British Pharmacopoeia (2012); Stationary Office London, UK.

4. Insel, A. P . (1990); Analgesic - Antipyretics and Anti-inflammatory Agents; Drugs employed in the treatment of rheumatoid arthritis and gout. In: Goodman and Gilman's The Pharmacological Basis of Therapeutics; Pergamon Press Inc, New York

5. Boyce, E. G. (2006); Rheumatoid arthritis; In: Helms, R. A.; Quan, D. J.; Herfindal E. T and Gourley, D.R (Eds.) Textbook of Therapeutics, Drug and Disease Management; $8^{\text {th }}$ Ed., Lippincott Williams and Wilkins, Philadelphia pp. 1705-1736.

6. Arakeri, V.; Ashok Kumar P. and Kulkarni, S. V (2014); Design and In Vitro Evaluation of Sustained Release Matrix Tablets of Repaglinide; International Journal for Pharmaceutical Research Scholars 4(3), 142-152.

7. Guerra-Ponce, W. L.; Gracia-Vasquez, S. L.; Gonzalez-Barranco, P.; Camacho-Mora, I. A.; Gracia-Vasquez, Y. A.; Orozco-Beltran, E. And Felton, L. A. (2016); In vitro evaluation of sustained released matrix tablets containing ibuprofen: a model poorly water-soluble drug; Brazilian Journal of Pharmaceutical Sciences; 52(4), 751-759.

8. Rubinstein, M. H. (1999); Tablets. In Michael Aulton (ed.), Pharmaceutics: The Science of Dosage Form Design; International Students Edition. Churchill Livingstone, UK.

9. Reza, M. S.; Quadir, M. A. and Haider, S. S. (2003); Comparative evaluation of plastic, hydrophilic and hydrophobic polymers as matrices for controlled release drug delivery; J. Pharm. Pharmaceut. Sci. $6(2), 274-291$.

10. Lordi, N. G. (1990); Sustained Release Dosage Forms. In Lachman L., Lieberman H.A and Kanig J. L. (eds.).The Theory and Practice of Industrial Pharmacy. $3^{\text {rd }}$ ed. Bombay: Varghese Publishing House

11. Talukder, M. M.; Michael, A.; Rombaut, P. and Kinget, R. (1996); Comparative Study on Xanthan Gum and Hydroxypropylmethylcellulose as Matrices for Controlled-Release Drug Delivery; Int. J Pharm. $129,231-241$.

12. Rojas, J.; Gonzalez, C.; Rico, C. and Saez, O. (2011). Formulation of a modified release metformin. $\mathrm{HCl}$ matrix tablet: influence of some hydrophilic polymers on release rate and in-vitro evaluation; Brazilian Journal of Pharmaceutical Sciences 47(3), 483-493. 
13. Palo, A. K.; Ghose, D.; Saha, G.; Subudhi, S. K. and Pattnaik, S. (2014); Formulation and evaluation of metformin $\mathrm{HCl}$ sustained release tablet using hydrophilic polymers; Journal of Advanced Pharmaceutical Research 5(1), 1-13.

14. Goyal, S.; Agarwal, G.; Agarwal, S. and Karar, P. K. (2017); Oral sustained release tablets: An overview with a special emphasis on matrix tablet; American Journal of Advanced Drug Delivery 5(02), 064-076.

15. Salsa, T. ; Veiga, F. and Pina, M. E. (1997). Oral controlled release dosage form. I. Cellulose ether polymers in hydrophilic matrices; Drug Develop. and Ind. Pharm. 23, 929-938.

16. Basak, S.; Reddy, J. B. and Mani, L. K. (2006); Formulation and release behavior of sustained release ambroxol hydrochloride HPMC matrix tablet; Indian J. Pharm. Sci. 68, 594-598.

17. Kumar, J. A.; Rajesh, M.; Kumar, S. M.; Kulkarni, T. G. and Gopal, V. (2015); Formulation and in vitro evaluation of Araucaria bidwilli gum-based sustained release matrix tablets of diclofenac sodium; JPRHC. $3(1), 15-21$.

18. Deveswaran, R.; Abraham, S.; Bharath, S.; Basavaraj, B. V.; Furtado, S. and Madhavan, V. (2009); Design and characterization of diclofenac sodium tablets containing tamarind seed polysaccharide as release retardant; International Journal of PharmTech Research. 1(2), 191-195.

19. Nwosu, J. N.; Ogueke, C. C.; Owuamanam, C. I. and Onuegbu, N. (2011); The Effect of Storage Conditions on the Proximate and Rheological Properties of Soup Thickener Brachystegia eurycoma (Achi); Report and Opinion. 3(5), 52-58.

20. Ikegwu, O. E.; Okechukwu, P. E. and Ekumankana, E. O. (2010); Physico-chemical and pasting characteristics of flour and starch from achi, Brachystegia eurycoma seed; Journal of Food Technology. 8(2), 58-66.

21. Osazuwa, E. Q. and Uhumwangho, M. U. (2013); Potential of Brachystegia eurycoma gum in ameliorating brittle fracture during tableting; Nig. J Sci and Envr. 12 (1), 98-102.
22. Uhumwangho, M. U. and Ileje, I. L. (2014); Preliminary evaluation of the suspending properties of Brachystegia eurycoma gum on metronidazole suspension; International Current Pharmaceutical Journal. 3(11), 328-330.

23. Onyechi, J. O. and Okafo, S. E. (2016); Evaluation of carnauba wax in sustained release diclofenac sodium tablet formulation; J. Chem. Pharm. Res., 8(3), 714-721.

24. Ariania, L.; Silvia, S. and Hayun (2016); Formulation of diclofenac sodium sustained release tablet using coprocessed excipients of cross-linked amylose-xanthan gum as matrix; Int $\mathbf{J}$ Pharm Pharm Sci. 8(6), 151-155.

25. Uzondu, A. L.; Nwadike, K. N. and Okoye, E. I. (2014 ); Application of Brachystegia eurycoma GumEgg Albumen Mixture in the Formulation of Modified Release Metronidazole Tablets; Int. J. Pharm. Sci. Drug Res. 6(2), 109-113.

26. Higuchi, T. (1963); Mechanism of sustained action medication: Theoretical analysis of rate of release of solid drugs dispersed in solid matrices; J. Pharm. Sci. 52, 1145-1149.

27. Hixson, A. W. and Crowell, J. H. (1931); Dependence of reaction velocity upon surface and agitation; Ind. Eng. Chem. 23, 923-31.

28. Avbunudiogba, J. A. (2019); Modification of the Release Profiles of Theophylline Matrix Tablets by inclusion of Water Excipients; Nig J Pharm Appl Sci Res, 8(2), 107-113.

29. Korsmeyer, R. W.; Gurny, R.; Doelker, E.; Buri, P. and Peppas NA. (1983); Mechanisms of solute release from porous hydrophilic polymers; Int. J. Pharm. 15, 25-35.

30. Siepmann, J. and Peppas, N. A. (2001); Modeling of drug release from delivery systems based on Hydroxypropylmethylcellulose (HPMC)); Adv. Drug Deliv. Rev. 48, 139-57.

31. United States Pharmacopeia 29 - NF 24 pp. 3046.

32. United States Pharmacopeial Convention. Revision Bulletin, March 2009 